\title{
ANALISIS KEAMANAN WIRELESS LOCAL AREA NETWORK (WLAN) TERHADAP SERANGAN BRUTE FORCE DENGAN METODE PENETRATION TESTING (Studi kasus:RS H.LMANAMBAI ABDULKADIR)
}

\author{
Yudi mulyanto $^{1^{*}}$, herfandi ${ }^{2}$, randi candra kirana ${ }^{3}$ \\ 1,2,3,4Program Studi Teknik Informatika, Universitas Teknologi Sumbawa \\ email: randicandra4@gmail.com*
}

\begin{abstract}
Abstrak: Informasi dan komunikasi pada saat ini mutlak menjadi suatu kebutuhan pokok yang harus dipenuhi.Bahkan untuk sebagian orang, mereka memerlukan informasi kapan pun dan dimanapun mereka berada Dan teknologi yang mampu memenuhi kebutuhan tersebut adalah teknologi wireless.Pada wawancara dengan Bapak yudi alfiandi selaku unit Teknologi Informasi.Bahwa RS H.LManambai Abdulkadirsering terjadi gangguan seperti flooding dan illegal access.Maka dari itu RS H.LManambai Abdulkadirmembutuhkan analisis sistem keamanan jaringan agar dapat memastikan bahwa RS H.LManambai Abdulkadirbaik dalam segi sistem keamanan jaringannya terutama jaringan wireless.Maka dari itu dibutuhkan sebuah tools standar dalam analisis dengan menggunakan metodePenetration Testing.Hasil dari pengujian yang telah dilakukan,bahwa access poin 1 memiliki password yang sangat mudah di tebak dan rentan tehadap serangan, sehingga perlu penanganan yang lebih baik serta mengunakan passphrase.
\end{abstract}

Kata Kunci :Analisis, keamanan Jaringan, wireless, brute force, Penetration Testing

Abstract: Information and communication at this time absolutely become a basic need that must be met. Even for some people, they need information whenever and wherever they are. And the technology that can fulfill this need is wireless technology. In an interview with Mr. yudi alfiandi as the Information Technology unit. Whereas $R$ S H.L Manambai Abdulkadir often experienced disturbances such as flooding and illegal access. Therefore $R S$ H.L Manambai Abdulkadir needs a network security system analysis in order to ensure that $R$ S H.L Manambai Abdulkadir is good in terms of network security systems, especially wireless networks. Therefore, a standard tool is needed in analysis using the Penetration Testing method. The results of the tests that have been carried out, that access point 1 has a password that is very easy to guess and vulnerable to attacks, so it needs better handling and uses a passphrase.

Keywords: Analysis, Network security, wireless, brute force, Penetration Testing

\section{PENDAHULUAN}

\section{A. Latar belakang}

Informasi dan komunikasi pada saat ini mutlak menjadi suatu kebutuhan pokok yang harus dipenuhi. Bahkan untuk sebagian orang, mereka memerlukan informasi kapan pun dan dimanapun mereka berada Dan teknologi yang mampu memenuhi kebutuhan tersebut adalah teknologi wireless. Oleh karena itu, manusia harus terus mengejar dan meningkatkan kualitasdan kuantitas teknologi komunikasi. dengan banyaknya akses ke jaringan internet maka akan banyak pula peluang kejahatan yang terjadi didalam jaringan tersebut, misalkan adanya pencurian data yang terjadi dijaringan tersebut ataupun adanya peretas yang mematikan sumber daya jaringan tersebut. Kejahatan yang dimaksud berupa serangan yang bisa saja bertujuan untuk mendapatkan sumber daya, merubah konfigurasi sistem jaringan yang ada, memanipulasi data misalnya mengakses Server untuk merubah konfigurasi jaringan tertentu.

Wireless merupakan suatu hubungan telekomunikasi yang menggunakan gelombang elektromagnetik untuk dapat mengganti media kabel sebagai alat transfer data yang menawarkan beragam kemudahan, kebebasan, mobilitas, dan fleksibilitas yang tinggi. Teknologi wireless memiliki cukup banyak kelebihan dibandingkan teknologi kabel yang sudah ada. Kemudahan-kemudahan yang ditawarkan wireless LAN menjadi data tarik tersendiri bagi para pengguna komputer dalam menggunakan teknologi ini untuk mengakses suatu jaringan komputer atau internet.

RS H.L Manambai Abdulkadir terletak dikota sumbawa Profinsi Nusa Tengara Barat saat ini mengunakan Jaringan yang terdiri dari 6 perangkat wireless yang mencakup seluruh bidang di kantor menggunakan keamanan WPA2-PSK. Wireless yang di gunakan lebih sering mengalami masalahpada sistem kamanan jaringan dibandingkan menggunakan jaringan LAN. Adapun jenis serangan yang terjadi adalah Brute Force seperti flooding, illegal access yang berarti metode untuk meretas password dengan cara mencoba semua kemungkinan kombinasi yang ada pada wordlist. Serangan flooding terhadap perangkat wifi yang berimbas pada PC dan mengakibatkan PC tersebut tidak dapat mengakses internet.

Untuk itu penulis melakukan analisis menggunakan Penetration Testing yang merupakan salah satu tools yang dikembangkan oleh organitation untuk menjadi standar dalam menganalisis sistem keamanan jaringan pada sebuah instansi atau perusahaan, dalam kasus inimaka peneliti mengambil judul: ANALISIS KEAMANAN WIRELESS LOCAL AREA NETWORK (WLAN) 


\section{TERHADAP SERANGAN BRUTE FORCE DENGAN METODE PENETRATION TESTING \\ B. Rumusan Masalah}

Berdasarkan latar belakang permasalahan di atas maka rumusan masalah yang dapat di simpulkan adalah "Bagaimana Cara Menganalisis Keamanan Wireless Local Area Network (WLAN) Terhadap Serangan Brute Force Dengan Metode Penetration Testing Pada RS H.L Manambai Abdulkadir?"

\section{Batasan Masalah}

Pembatasan suatu masalah di gunakan untuk menghindari adanya penyimpangan maupun pelebaran pokok masalah supaya penelitian tersebut lebih terarah dan memudahkan dalam pembahasan sehingga tujuan penelitian akan tercapai. Dalam penelitian ini penulis membatasi masalah yang akan di analisa yaitu:

1. Penelitian hanya mencangkup perangkat wireless

2. Pengujian hanya dilakukan pada perangkat wifi di unit ITRS H.Lmanambai abdulkadir.

3. Penelitian ini mengunakan metode

Penetration Testing(Intelligence

Gathering,Threat Modeling,Reporting)

\section{Tujuan penelitian}

Maksud dari penelitian ini adalah menganalisis sistem keamanan jaringan RS H.Lmanambai abdulkadir dengan menggunakan metode penetration testing, sehingga penulis mengetahui baik atau tidaknya sistem keamanan jaringan wireless di RS H.L manambai abdulkadir. Sedangkan tujuan dari penelitian ini adalah sebagai berikut:

1. Menganalisi sistem keamanan wireless yang telah diterapkan RS H.Lmanambai abdulkadir.

2. Menerapkan Penetration Testing dalam menganalisis sistem keamanan jariangan wireless

\section{LANDASAN TEORI}

\section{TINJAUAN PUSTAKA}

Ada beberapa penelitian lain yang telah dilakukan oleh peneliti sebelumnya yang mempunyai keselarasan dengan penelitian ini. Berikut adalah beberapa penelitian yang dijadikan sebagai referensi oleh penulis dalam melakukan penelitian ini:

Penelitian yang di lakukan oleh Imam Kreshna Bayu, dkk (2017) [1] yang berjudul "Analisa keamanan jaringan wlan dengan metode penetration testing" dalam penelitian ini menggunakan metode penetration Testing, Singkatnya, tujuan pengujian penetrasi hanya untuk melindungi organisasi. Dengan menggunakan hasil uji penetrasi yang efektif, organisasi yang berpartisipasi dapat mengidentifikasi dan mengurangi kerentanan. Penelitan sebelumnya hanya menerapankan tahapan plenning sedangkan penulis mengunkan Tahapan Intelligence Gathering, Threat Modelingand reporting.

Penelitian selanjutnya oleh Desi Maya Sari, dkk (2017) [2] yang berjudul "Analisis sistem keamanan jaringan wireless (wep, wpapsk/wpa2psk) mac address, menggunakan metode penetration testing". Hasil dari penelitian ini adalah pengujian terhadap jaringan wireless dengan dua jenis serangan: cracking the encryption dan bypassing wlan authentication terhadap tipe keamanan wlan yaitu WEP, WPAPSK/WPA2PSK, dan Mac Address. Dengan menggunakan metode analisis yang di gunakan Penetration Testing (Pentest). Tetapi penelitian sebelumnya hanya mangunakan tools dari kali linux sedangakan penulis mengunaan aplikasi vpn book.

Harry Dwi Sabdho, dkk (2018) [3] dalam penelitiannya yang berjudul "Analisis Keamanan Jaringan Wireless menggunakan Metode Penetration Testing Pada Kantor Pt. Mora Telematika Indonesia Regional Palembang" dengan menggunakan metode pengembangan yang di gunakan Penetration Testing (Pentest).Hasil dalam penelitiannya yaitu kegiatan evaluasi ini dilakukan agar mengetahui tingkat kerentanan dalam jaringan wireless local area network, dengan melakukan 4 tahapan penyerangan maka terbukti kerentanan jaringan wireless local area network yang di miliki PT. Mora Telematika Indonesia bisa di katakan lemah. Dalam penelitiannya Tidak mengunakan tahapan Penetration Testing Melainkan menguakan tools dari kali linux.

Dwi Bayu Rendro, dkk (2020) [4] dalam penelitiannya yang berjudul “Analisis Monitoring Sistem Keamanan Jaringan Komputer Menggunakan Software Nmap" dalam penelitiannya menggunakan Metode meliputi analisis, monitoring, dan observasi. Didapat bahwa seorang sysadmin mampu melakukan scanning jaringan secara mudah untuk mendapatkan informasi yang ada pada jaringan. Seperti pemindai port jaringan dengan versi layanan dan mesin pendeteksi sistem operasi. User Nmap juga dapat melihat rute jaringan yang dilewati dalam mengakses sumber host target, seperti host jaringan dan host website. Terdapat Perbedaan dengan penelitian yang penulis lakukan adalah penulis malakukan analisis sedangkan penelitian sebelumnya melakukan pengembangan jaringan yang sudah ada.

Penelitiaan yang di lakukan oleh Abraham Yano Suharmanto, dkk (2018) [5] engan judul “ Analisa Keamanan Jaringan Wireless Di Universitas Sam Ratulangi” hasil dari penelitian ini adalah Bahwa keamanan jaringan dan website Unsrat belum sepenuhnya dapat dikatakan aman, walaupun masih dikatakan belum aman tetapi tingkat ancaman yang ditunjukkan hanya berada di level 2 dan tidak mendapatkan tingkat keamanan pada level high pada web alert akan tetapi jaringan 
unsrat masih bisa terkena Flooding dan metode penyerangan DDOS masih bisa dilakukan. Dengan menggunakan Metode meliputi analisis, monitoring,observasi. Terdapat perbedaan penelitian perbedaan pada segi metode

yang digunakan dan hasil yang didapat.

Rizky Wahyu Ismail, dkk (2020) [6] dalam penelitiannya yang berjudul "Metode Penetration Testing pada Keamanan Jaringan Wireless Wardriving PT. Puma Makmur Aneka Engineering Bekasi” yang menggunakan metode pengembangan yang di gunakan Penetration Testing (Pentest), mendapatkan Hasil pengujian keamanan jaringan internal dan publik telah dilakukan dengan menggunakan metode Penetration Testing dan mendapatkan kerentanan seperti WPA2 Cracking, Dos, Paswword Router Wireless Cracking, dan AP Isolation Testing sehingga diketahui kerentanan pada jaringan internal dan publik. Terdapat perbedaan Penelitan yang sebelumya tidak menggunakan tahanpan reporting. sedangkan penulis mengunkan Tahapan reporting sebagai tahapan akhir penelitian.

\section{Dasar teori}

1. Analisis

Secara umum analisi (Menurut John W. Creswell, 2013) [8] adalah sebuah kemampuan memecahkan atau menguraikan suatu materi atau informasi menjadi komponen-komponen yang lebih kecil sehingga lebih mudah dipahami.Analisis data merupakan bagian yang amat penting dalam metode ilmiah.Dengan analisis, data tersebut dapat berguna dalam memecahkan masalah penelitian.

\section{Keamanan Jaringan}

Keamanan jaringan komputer sebagai bagian dari sebuah sistem sangat penting untuk menjaga validitas dan integritas data serta menjamin ketersediaan layanan bagi penggunaannya.Sistem keamanan jaringan komputer harus dilindungi dari segala macam serangandan usaha-usaha penyusupan atau pemindaian oleh pihak yang tidak berhak.

Sistem deteksi penyusup jaringan yang ada saat ini umumnya mampu mendeteksi berbagai jenis serangan tetapi tidak mampu mengambil tindakan lebih lanjut.Selain itu sistem juga tidak memiliki interaktivitas dengan administrator pada saat administrator tidak sedang mengadministrasi sistemnya. Hal ini merupakan suatu hal yang tidak efektif terutama pada saat sistem berada dalam kondisi kritis [11]

\section{a. Privacy}

Privacy dalam hal ini adalah pengirim dan penerima membutuhkan kerahasiaan. Hanya pengirim dan penerima yang dapat memahami pesan yang ditransmisikan. Salah satu tindakan yang digunakan untuk mencapai aspek Privacy ini adalah dengan melakukan enkripsi data, yang menjadikan data tersebut tidak dapat dimengerti oleh orang lain.

\section{b. Message Integrity}

Integritas data atau pesan yang dimaksud di sini adalah bahwa data harus sampai ke penerima persis seperti yang dikirimkan. Di dalam jaringan internet, data yang dikirim dapat saja dirubah oleh si apapun sehingga data yang diterima menjadi berbeda.

\section{c. End Point Authentication}

Autentikasi di sini dilakukan dengan tujuan penerima yakin dengan identitas pengirim.

\section{d. Non-repudiation}

Non-repudiation berarti penerima harus dapat membuktikan bahwa pesan yang diterima berasal dari pengirim tertentu. Pengirim tidak boleh menolak untuk mengirim pesan yang dia kirim. Beban untuk membuktikan identitas ada pada si penerima.

\section{WirelessLocal Area Network (WLAN)}

Ada beberapa pendapat ahli tentang wreless yang dapat diartikan berbagai macam sesuai dengan permasalahan yang di analisis. Berikut adalah pendapat beberapa ahli :

Menurut ( Nurul hayati, 2020) [11] Jaringan tanpa kabel (wireless) atau jaringan nirkabel merupakan suatu jalan keluar terhadap komunikasi yang tidak bisa dilakukan dengan jaringan yang menggunakan kabel. Pada saat ini jaringan nirkabel atau wirelesssudah banyak digunakan dengan memanfaatkan jasa satelit dan bahkan mampu memberi kecepatan akses yang lebih cepat bila dibandingkan dengan jaringan yang menggunakan kabel.

Sedagkan menrut (Agung Suprapto, 2020) [7] wirless adalah Jaringan nirkabel atau jaringan wireless adalah jaringan komputer yang menggunakan media udara yang mengantarkan gelombang elektromagnetik untuk menghubungkan antar perangkat.

Dapat di simpulkan bahwa jaringan wireless (nirkabel) merupakan jaringan nirkabel yang terkoneksi dengan menggunakan gelombang udara atau nirkabel (wireless). Teknologi ini terkoneksi tanpa menggunakan kabel atau perangkat elektronika lainnya sebagai media transmisi

\section{Jaringan Komputer}

Kemajuan jaringan komputer sekarang ini sudah sangat melekat dengan gaya hidup manusia moderen. Hampir setiap peralatan berbasis komputer memanfaatkan jaringan komputer untuk berkomunikasi data, baik komunikasi dengan device yang sama, maupun berbeda. Jaringan komputer adalah cikal bakal munculnya teknologi internet 
yang saat ini sangat berpengaruh di kehidupan manusia moderen. Pengetahuan tentang jaringan komputer menjadi fondasi penting untuk mengembangkan teknologi canggih masa depan yang berjalan di atas internet. [7]

\section{Brute force}

Serangan brute force mengunakan trial-enderror untuk menebak info login, kunci enkripsi, atau menemukan halaman web yang tersembunyi. Peretas bekerja melalui semua kemungkinan kombinasi dengan harapan dapat menebak dengan benar.

Serangan ini dilakukan dengan 'berute force'yang berarti mereka mengunakan upaya paksa yeng berlebihan untuk mencoba dan memaksa masuk ke akun pribadi.

Metode ini adalah serangan lama, tetapi masih efektif dan populer di kalangan peretas. Karena tergantung pada panjang dan kerumitan kata sandi, memecahkanya bisa memakan waktu mulai dari beberapa detik hingga bertahun-tahun [9]

\section{Penetration Testing}

Penetration Testing adalah metode Pengujian penetrasi, atau pentesting (jangan dikelirukan dengan pengujian ballpoint atau pulpen), melibatkan simulasi serangan nyata untuk menilai risiko yang terkait dengan potensi pelanggaran keamanan. Pada pentest (sebagai lawan dari penilaian kerentanan), penguji tidak hanya menemukan kerentanan yang dapat digunakan oleh penyerang tetapi juga mengeksploitasi kerentanan, jika memungkinkan, untuk menilai apa yang mungkin diperoleh penyerang setelah eksploitasi yang berhasil. [10]

Tabel 1 Perbandiangan antara metode penetration testing dan vulnerability assessment

\begin{tabular}{|l|l|}
\hline \multicolumn{1}{|c|}{ Penetration Testing } & \multicolumn{1}{c|}{$\begin{array}{c}\text { Vulnerability } \\
\text { Assessment }\end{array}$} \\
\hline $\begin{array}{l}\text { Berfokus pada pencarian } \\
\text { kerentan saja. }\end{array}$ & $\begin{array}{l}\text { Tidak hanya mencari } \\
\text { celah kerentanan saja, } \\
\text { tetapi dapat melakukan } \\
\text { eksploitasi. }\end{array}$ \\
\hline $\begin{array}{l}\text { Identifikasi beberapa } \\
\text { celah keamanan. }\end{array}$ & $\begin{array}{l}\text { Identifikasi semua celah } \\
\text { keamanan. }\end{array}$ \\
\hline Pendekatan risiko IT. & $\begin{array}{l}\text { Pendekatan bisnis dan } \\
\text { risiko IT. }\end{array}$ \\
\hline $\begin{array}{l}\text { Pembuktian secara } \\
\text { teknis. }\end{array}$ & Pembuktian secara teori. \\
\hline
\end{tabular}

Dari kedua metode penelitian diatas, penulis menggunakan Metode PENTEST karena tahapan dalam Metode PENTEST ini sesuai dengan tema penelitian yang akan penulis kerjakan yaitu menganalisis keamanan Wireless.

\section{Perbandingan Metode Pengumpulan Data Kualitatif Dan Kuantitatif}

Tabel 2 Perbandingan Metode Pengumpulan Data Kualitatif Dan Kuantitatif

\begin{tabular}{|c|c|c|}
\hline Unsur & Kualitatif & Kuantitatif \\
\hline $\begin{array}{l}\text { Secara } \\
\text { umum }\end{array}$ & $\begin{array}{l}\text { Merupakan sebuah } \\
\text { metode yang } \\
\text { menekankan pada aspek } \\
\text { pemahaman lebih } \\
\text { mendalam terhadap } \\
\text { suatu masalah dari pada } \\
\text { melihat sebuah } \\
\text { permasalahan. }\end{array}$ & $\begin{array}{l}\text { Adalah sebuah penelitian } \\
\text { riset yang sifatnya deskripsi, } \\
\text { cenderung menggunakan } \\
\text { analisis dan lebih } \\
\text { menampakkan proses } \\
\text { makananya. }\end{array}$ \\
\hline
\end{tabular}

\begin{tabular}{|c|c|c|}
\hline $\begin{array}{l}\text { Kejelasan } \\
\text { unsure }\end{array}$ & $\begin{array}{l}\text { Tujuan, pendekatan, } \\
\text { subjek, sumber data } \\
\text { sudah mantap dan } \\
\text { rinci sejak awal }\end{array}$ & $\begin{array}{l}\text { Subjek sample, sumber } \\
\text { data tidak mantap dan } \\
\text { rinci, masih flexsibel, } \\
\text { timbul dan } \\
\text { berkembangnya sambil } \\
\text { jalan. }\end{array}$ \\
\hline $\begin{array}{l}\text { Langkah } \\
\text { penelitian }\end{array}$ & $\begin{array}{l}\text { Segala sesuatu di } \\
\text { rencanakan sampai } \\
\text { matang } \\
\text { ketika persiapan } \\
\text { disusun. }\end{array}$ & $\begin{array}{l}\text { Baru diketahui dengan } \\
\text { mantap dan jelas setelah } \\
\text { penelitian } \\
\text { selesai. }\end{array}$ \\
\hline Desain & $\begin{array}{l}\text { Desain Langkah- } \\
\text { langkah penelitian } \\
\text { dan hasilyang } \\
\text { diharapkan }\end{array}$ & $\begin{array}{l}\text { Desain penelitiannya } \\
\text { adalah flexsibel dengan } \\
\text { langakah dan hasilyang } \\
\text { tidak dapat } \\
\text { dipastikan sebelumnya. }\end{array}$ \\
\hline $\begin{array}{l}\text { Pengumpul } \\
\text { an data }\end{array}$ & $\begin{array}{l}\text { Kegiatan pengumpulan } \\
\text { data memungkinkan } \\
\text { untuk diwakilkan }\end{array}$ & $\begin{array}{l}\text { Kegiatan pengumpulan data } \\
\text { harus selalu dilakukan } \\
\text { oleh peneliti sendiri. }\end{array}$ \\
\hline $\begin{array}{l}\text { Instrument } \\
\text { penelitian }\end{array}$ & $\begin{array}{l}\text { Berupa koisioner yang } \\
\text { tidak boleh } \\
\text { diinterpretasikan oleh } \\
\text { pengedar koisioner } \\
\text { dan tidak juga boleh } \\
\text { ditambahatau } \\
\text { dikurangi }\end{array}$ & $\begin{array}{l}\text { Instrument penelitian } \\
\text { adalah peneliti sendiri, } \\
\text { sehingga peneliti harus } \\
\text { konseptual dan teoritikal }\end{array}$ \\
\hline
\end{tabular}

Dari kedua metode pengumpulan data kualitatif dan kuantitatif yang telah di jelaskan diatas penulis menggunakan metode pengumpulan data Kualitatif, Penelitian kualitatif merupakan penelitian yang bersifat deskriptif dan cenderung menggunakan analisis. Proses dan makna (prespektif subjek) lebih ditonjolkan dalam penelitian kualitatif. Landasan teori dimanfaaatkan sebagai pemandu agar fokus penelitian sesuai dengan fakta dilapangan, karena metode pengumpulan data Kualitatif cocok dengan metode analisis. [12]

\section{Jenis Ancaman Jaringan Komputer}

Menurut (Agung Suprapto, 2020) [7] Terdapat beberapa macam jenis serangan dalam jaringan komputer, yaitu:

\section{a. Spoofing}

Serangan jenis ini adalah salah satu metode serangan Man in the Middle Attack (MITM). Cara yang dilakukan penyerang adalah dengan 
memalsukan IP address dari sebuah domain, dan mengarahkan lalu lintas data ke penyerang. Serangan ini juga disebut dengan DNS Cache Poisoning.

\section{b. DDoS (Distributed Denial of Service)}

Yaitu jenis serangan terhadap server pada suatu jaringan dengan menggunakan metode menghabiskan resource yang dimiliki oleh server sampai tidak dapat menjalankan fungsinya.

\section{c. Packet Sniffing}

Yaitu jenis serangan yang melakukan pencurian data dengan cara me-monitoring dan menganalisis setiap paket data yang dilewatkan dari client ke server. Tahap-tahapdalam packetsniffing adalah (1) collectiong, (2) conversion, (3) analysis, (4) pencurian data

\section{d. DNS Poisoning}

Yaitu jenis serangan dengan cara memberikan informasi IP Addressyang palsu, yang bertujuan untuk mengalihkan trafik pada paket data dari tujuan yang sebenarnya.

\section{e. Trojan Horse}

Yaitu jenis serangan yang digunakan untuk memperoleh informasi dari target, seperti password, system log, dll. Trojan horse adalah salah satu Malicioussoftware (Malware) yang dapat merusak sebuah sistem.

\section{f. SQL Injection}

Yaitu jenis serangan yang memanfaatkan celah keamanan. SQL Injection adalah salah satu teknik yang menyalahgunakan celah keamanan yang ada di SQL pada lapisan basis data suatu aplikasi. Celah ini terjadi karena input dari user tidak difilter secara benar dan dalam pembuatannya menggunakan form yang salah. Jadi sampai saat ini SQL Injection masih menjadi favorit hacker untuk melakukan serangan pada website. Apalagi sekarang ini hacking melalui jaringan internet sudah tidak semudah zaman dulu. Contoh mudah teknik SQL Injection melalui form username harusnya username diisi dengan karakter saja, tetapi form tersebut bisa diisi dengan karakter lain, jadi hacker bisa menyisipkan karakter seperti $(: ;-,=’)$ sehingga hacker bisa memasukan query SQL Injection, akibatnya yang pasti website Anda sudah bisa ditembus oleh hacker tersebut.

\section{METODOLOGI PENELITIAN}

\section{A. Medote Penelitian}

Dalam melakukan penelitian ini, Peneliti menggunakan analisa penelitian kualitatif yang bersifat deskriptif. Hal ini dikarenakan sifat permasalahan yang menggambarkan atau mendeskripikan keadaan subjek atau objek yang diteliti. Adapun pada tahapan analisis sisyem jaringan yaitu sebagai berikut :

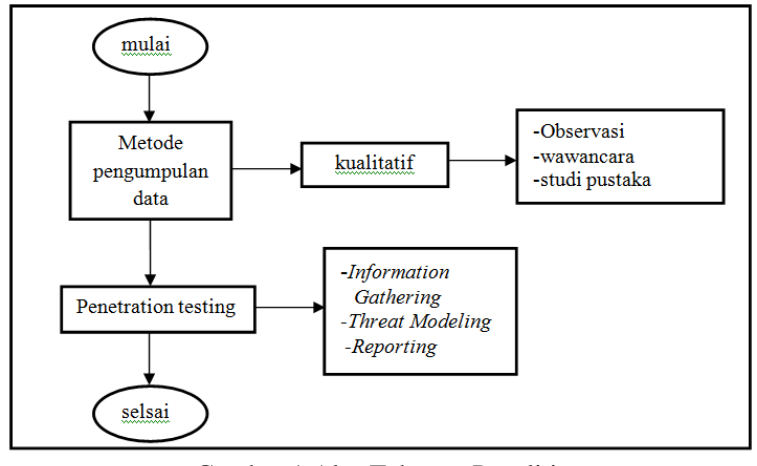

Gambar 1 Alur Tahapan Penelitian

\section{B. Metode pengumpulan data}

Berikut adalah bebarapa metode pengumpulan data yang peneliti gunakan dalam melakukan penelitian.

\section{Observasi}

Pada metode ini peneliti melakukan survei lokasi untuk mengumpulkan data-data RS H.L Manambai Abdulkadir. Survei ini dilakukan untuk mencari data perangkat wirelees dan data pengguna wirelees dan keamanan

\section{Wawancara}

Pada tahap ini peniliti melakukan wawancara terhadap kariawan di LAB computer RS H.L Manambai Abdulkadir. Untuk mendapatkan informasi terkait perkembangan dan fungsi keberadaan jaringan komuputer.

\section{Studi Pustaka}

Mencari data-data atau informasi mengenai judul skripsi yang berkaitan dengan permasalahan yang ada.Data dan informasi didapatkan dari jurnal, buku, skripsi terdahulu untuk membantu penelitian selanjutnya.

\section{Metode analisis sistem}

Berikut adalah alur dari bagian metodepeneterion testing (pentes) dalam melakukan Analisis yang penulis gunakan dalam melakukan penelitian:

\section{Information Gathering}

Dalam tahap ini, penulis melakukan pengumpulan data yang biasa dikategorikan sebagai passive penetration testing, karena pada tahap ini penulis pengumpulan data secara manual melului dokumentasi dari pihak yang terkait ataupun informasi yang bersifat terbuka pada pihak terkait dengan sistem yang akan diuji. Bentuk analisis ini berupa analisis jaringan dan topologi yang sedang berjalan, analisis kebutuhan user, serta perangkat lunak maupun perangkat keras yang di gunakan.

\section{Threat Modeling}

Merupakan tahap dimana penulisakan mencoba melalakukan simulasi serangan untuk 
mendapatkan username dan password dari wireless. Teknik penyerang yanga akan dilakukan menggunakan Brute force dan vpn book.

\section{Reporting}

Dalam tahap ini penulis menganalisi hasil dari tahap sebelumnya, kerentanan yang teridentifikasi selama pengujian, mengidentifikasi risiko, dan memberikan rekomendasi terkait langkah untuk mengurangi kerentanan yang ditemukan.

\section{Tempat Penelitian}

Penelitian Penelitian ini akan dilaksanakan di RS H.L Manambai Abdulkadir Jln. Lintas sumbawa bima Kecamatan unter iwes Kabupaten Sumbawa Provinsi Nusa Tenggara Barat.

\section{HASIL DAN PEMBAHASAN}

\section{A. Hasil Pengumpulan Data}

Adapun penerapan dari hasil metode Penetration Testing yang telah digunakan dari tahap Information Gathering, Threat Modeling, sampai dengan tahap Reporting. Pada penelitian ini dibagi atas pembahasan hasil pengumpulan data, hasil analisis pecobaaan serangan dan kerentanan jaringan serta meberikan langkah dan solusi untuk mengurangi kerentanan yang di temukan pada jaringan wireless rs h.l manambai abdulkadir

\section{Observasi}

Hasil dari observasi yang dilakukan oleh peneliti di RS H.L manambai Abdulkadir tersebut menyetujui dijadikan objek penelitian, dengan penelitian yang berjudul analisis keamanan wireless local area network (WLAN) terhadap serangan bruet force dengan metode penetration testing. RS H.L manambai Abdulkadir bersedia memberikan data dan informasi yang di teliti. Data yang di berikan berupa skema jaringan yang sedang di gunakan saat ini, dan hasil observasi, peneliti mendapatkan bahwa RS H.L manambai Abdul kadir dalam penerapan keamanan yang baik menggunakan settingan default dari acces poin untuk pengamanan terhadap wireless itu sendiri.

\section{Wawancara}

Pada tahap wawancara dilakukan dengan wawancara lagsung. Metode wawancara dilakukan dengan memberikan pertanyaan langsung kepada pihak IT RS H.Lmanambai Abdulkadir bagian dari proses wawancara yang dilakukan bahwa pihak tersebut mendukung dalam penelitian analisis keamanan jaringan di RS H.Lmanambai Abdulkadir.

\section{Studi pustaka}

Hasil dari studi pustaka yang penulis lakukan untuk memperkuat penelitian ini adalah dengan mencari referensi mengenai konsep dan teknik dari buku, jurnal, maupun tugas akhir yang di mana terdapat dalam tinjauan pustaka dan landasan teori di bab 2.

\section{B. Information Gathering}

Dari tahap information gathering yang telah di lakukan dapat di jabarkan beberapa point hasil analisis kebuthan perangkat, kebutuhan pengguna, dan kebutuhan layanan yang di perlukan.

1. Analisis Kebutuhan Perangkat Keras (Hardware)

Tabel 3 Spesifikasi Perangkat Keras

\begin{tabular}{|c|l|l|}
\hline No & Perangkat Keras & \multicolumn{1}{c|}{ Spesifikasi } \\
\hline 1. & Laptop & a. Processor Intel Celeron N3350 \\
& & 2.4 Ghz \\
& & b. RAM 4 GB DDR3 \\
& & c. Grafis: Intel HD Graphics \\
& & d. HDD 500gb \\
\hline
\end{tabular}

2. Analisis Kebutuhan Perangkat Lunak (Software)

Tabel 4 Spesifikasi Perangkat Lunak

\begin{tabular}{|c|l|l|}
\hline No & \multicolumn{1}{|c|}{ Prangkat Lunak } & \multicolumn{1}{|c|}{ Versi } \\
\hline 1. & Kali linux & $7(32$ Bit $)$ \\
\hline 2. & Google Chrome & 92.0 \\
\hline 5. & Pvn book & 3.4 .7 \\
\hline
\end{tabular}

3. Identitas Perangakat Yang Di Uji

\section{Acces poin TL-WR840N}

Wireless router ini dilengkapi dengan dua antena $5 \mathrm{dBi}$, TL-WR840N dapat meningkatkan transmisi sinyal nirkabel dan penerimaan. Dengan 4 port Ethernet cepat, ia menyediakan Wi-Fi yang andal dan koneksi kabel untuk rumah berukuran sedang, membiarkan keluarga Anda menikmati WiFi cepat bersama di setiap smartphone, tablet, dan laptop.

Sesuai dengan standar IEEE 802.11n, TLWR840N dapat membangun jaringan nirkabel dan mendapatkan hingga 15X kecepatan dan 5X kisaran produk $11 \mathrm{~g}$ konvensional. Juga, dengan tingkat transmisi hingga 300Mbps.

Table 5 identitas tp-ling TL-WR840N

\begin{tabular}{|l|l|l|l|}
\hline Spesifikasi & Kecepatn & $\begin{array}{c}\text { Frekuensi } \\
\text { band }\end{array}$ & Availability \\
\hline $802.11 \mathrm{~b}$ & $11 \mathrm{mb} / \mathrm{s}$ & $2.4 \mathrm{GHz}$ & $\mathrm{b}$ \\
\hline $802.11 \mathrm{~g}$ & $54 \mathrm{mb} / \mathrm{s}$ & $2.4 \mathrm{GHz}$ & $\mathrm{b}, \mathrm{g}$ \\
\hline $802.11 \mathrm{n}$ & $300 \mathrm{mb} / \mathrm{s}$ & $2.4 \mathrm{GHz}$ & $\mathrm{b}, \mathrm{g}, \mathrm{n}$ \\
\hline
\end{tabular}

\section{Threat Modeling}

Dari arsitektur dan topologi yang sudah penulis peroleh, pada tahap ini penulis akan melakukan simulasi penyerangan untuk mendapatkan password dari wireles. Dalam hal ini penulis akan, mensimulasikan diri sebagai peretas di dalam Jaringan RS H.L manambai Abdulkadir. 
Penyerangan akan di lakukan melalui wireless yang sudah di amankan mengunkan WPA/WPA2 PSK.

\section{Instalasi vpn book}

Berikut adalah langkah-langkah dalam instalasi vpn book dapat di lihat dari gambar di bawah ini

\section{Merubah Ipaddress pentester dengan tools vpn books}

Ip address yang digunakan oleh pentester adalah 192.168.106.183. Berikut ini adalah gambar penggilan informasi interface pentester. Dapat dilihat pada gambar

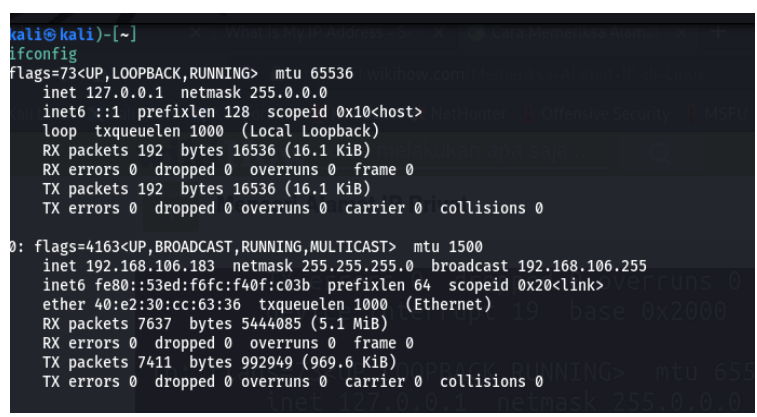

Gambar 2 pengecekan ip addres

\section{menginstal vpn book untuk merubah ip address}

Langkah untuk menginstall vpnbook dengan menuliskan perintah "openvpn vpnbook -pl226tcp80.ovpn" pada terminal linux berikut adalah tampilan dari menginstall vpnbook dapat dilihat pada gambar di bawah ini.

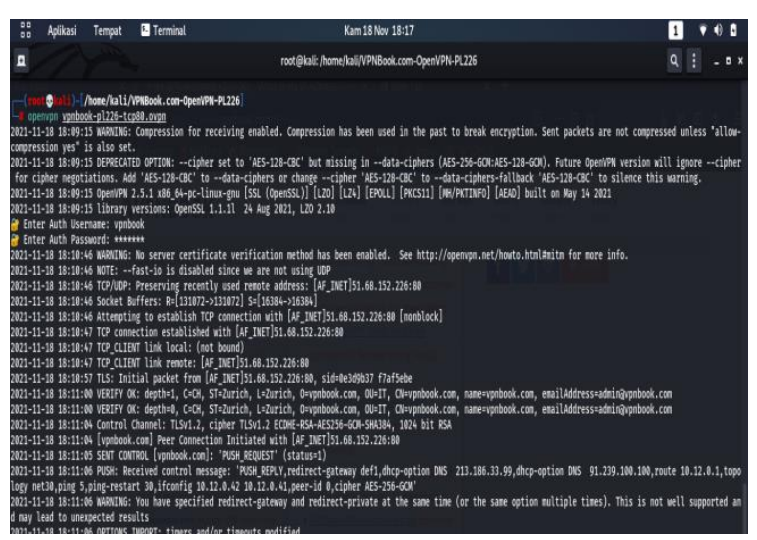

Gambar 3 penginstalan vpn book

\section{Pembuktian ipaddress telah dirubah}

Untuk membuktikan bahwa ipaddress telah berhasil dirubah maka dibuktikan dengan mengecek ip dan region dengan situs https://whatismyipaddress.com/berikut adalah tampilan ip yan telah dirubah dapat dilihat pada gambar

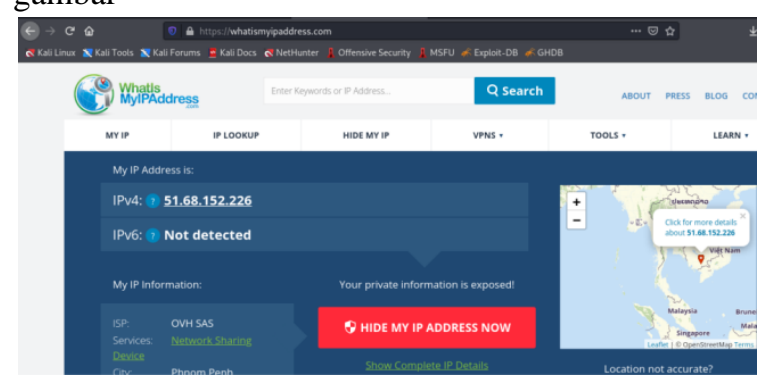

Gambar 4 pembuktian ip addres telah di rubah

\section{Flowchat brute force}

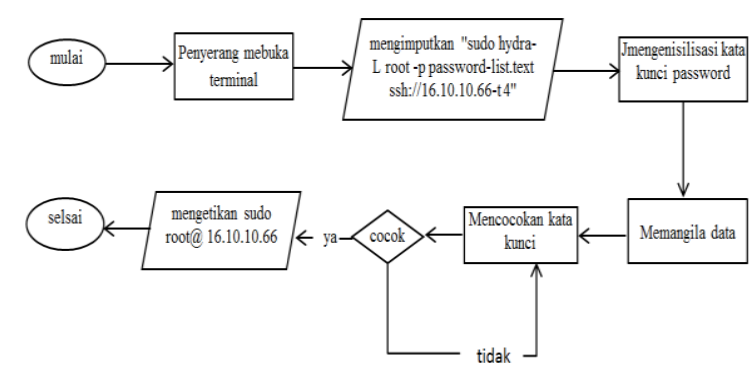

Gambar 5 flowchat brute force

Pada penyerangan SSH brute force ini penyerang berusaha untuk mendapatkan username dan password yang dimiliki server menggunakan aplikasi Hydra, dimana aplikasi ini berbasis command prompt. Penyerang berusaha menebak password dengan menginputkan perintah sesuai dengan gambar 1 Setelah perintah diinputkan maka aplikasi Hydra akan menginisialisasi kata kunci password yang kemudian dilakukan pemanggilan data. Hydra akan mencocokkan kata kunci password, jika terdapat kecocokan pada password-list.txt maka penyerang akan melakukan serangan SSH brute force terhadap server menggunakan mode root. Namun, apabila kata kunci password tidak mengalami kecocokan, maka akan mencocokkan kata kunci password kembali

\section{Mengaktifkan mode monitoring interface wilan}

Untuk menggunakan tools aircrack-ng diperlukan untuk mengaktifkan mode monitoring pada interface wlan0 menggunakan perintah " airmon-ng start wlan0". Berikut adalah tampilan dari mode monitoring dapat dilihat pada gambar berikut ini

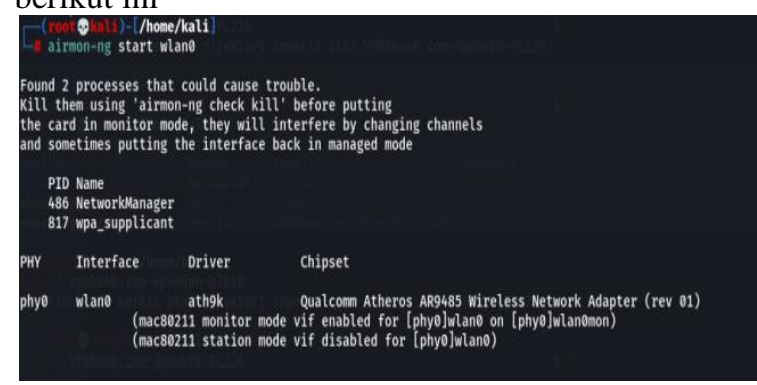

\section{Scaning wireless}


Perintah airodump-ng wlanOmon pada console digunakan untuk scanning wireless.Berikut ini adalah layar keluaran hasil dari mengetikan perintah airodump-ng wlanOmon dapat dilihat pada gambar berikut.

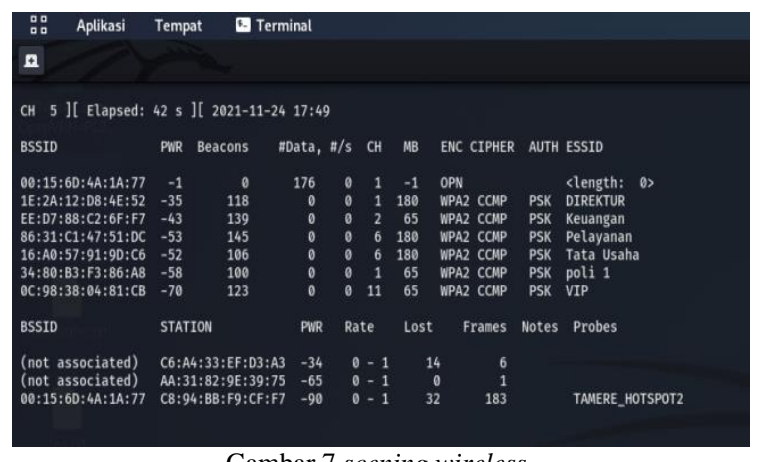

\section{Proses handshake}

Gambar 7 scening wireless

Perintah airodump-ng -w skripsi21 - C 1 -bssid 86:31:C1:47:51:DC wlan0mon digunakan untuk menghubungkan atau handshake interface pentester dengan perangkat wireless target. Berikut adalah tampilan dari handshake perangkat. Dapat dilihat pada gambar berikut.

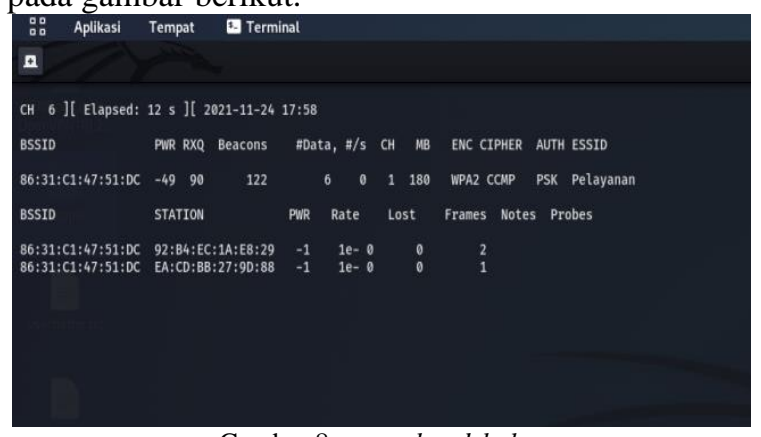

\section{Injeksi paket}

Gambar 8 proses handshake

Pada pintah aireplay-ng -deauth $50-a$ 86:31:C1:47:51:DC wlanOmon yaitu printah untuk memaksa mereka kluar dari wireless, kalo serasa udah cukup lagsung ctrl+c.

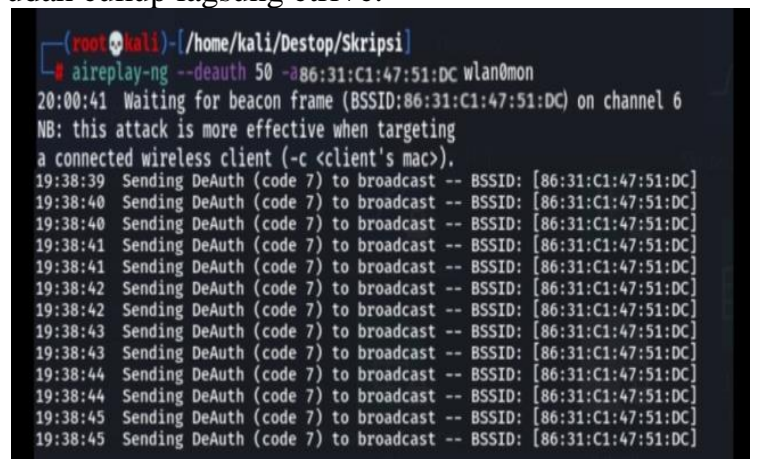

Gambar 9 melakukan injeksi paket

\section{7. hasil dari handshake}

Selanjutnya kita akan melihat ke folder apakah ada file yang telah disimpan sebelumnya. Dapat dilihat gambar 6 berikut.

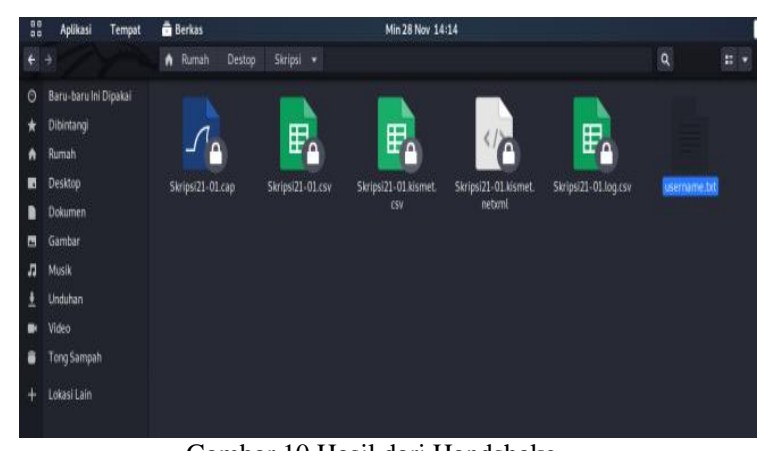

\section{Proses cracking 1}

Gambar 10 Hasil dari Handshake

Perintah aircrack-ng skripsi21-01.cap -w tes.tet di gunakan untuk mengload file lis yang sudah di buat oleh pentester dan menjalan tools aircrack-ng untuk melakukan brute force pada perangkat wireless target. Berikut adalah tampilan dari aircrack dapat dilihat pada gambar berikut.

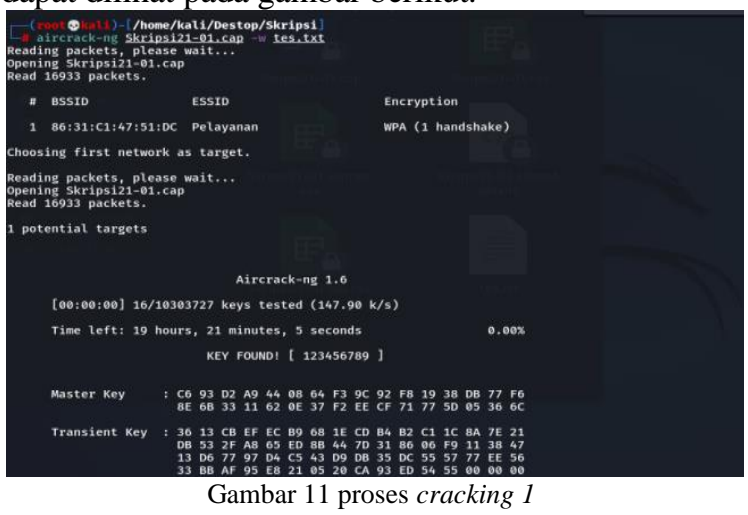

\section{Proses cracking 2}

Perintah aircrack-ng skripsi21-01.cap -w tes.tet di gunakan untuk mengload file list yang sudah di buat oleh pentester dan menjalankantoolsaircrack-ng untuk melakukan bruteforce pada perangkat wireless target.Berikut adalah tampilan dari aircrack dapat dilihat pada gambar berikut.

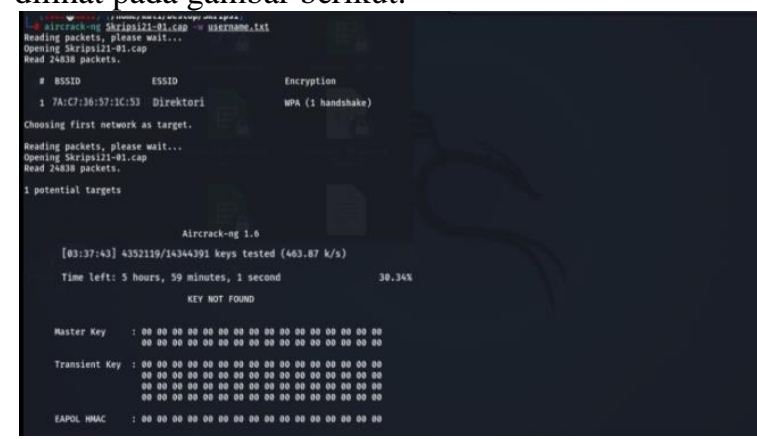

\section{Reporting}

Gambar 12 proses cracking 2

Dari Penelitian yang dilakukan, pada tahap reporting, penulis meyimpulkan hasil di antaranya, hasil pneyerangan access poin dan solusi untuk pengamanan Serangan brute force. 


\section{Tabel peneyerangan}

Tabel 6 hasil penyerangan

\begin{tabular}{|c|l|l|}
\hline Jenis Serangan & \multicolumn{1}{|c|}{$\begin{array}{c}\text { Informasi yang } \\
\text { dilbutuhkan }\end{array}$} & Status \\
\hline bruteforce attak & $\begin{array}{l}\text { Mendapatkan informasih } \\
\text { kemungkinan password }\end{array}$ & BERHASIL \\
\hline bruteforce attak & $\begin{array}{l}\text { Mendapatkan informasih } \\
\text { kemungkinan password }\end{array}$ & GAGAL \\
\hline
\end{tabular}

Dalam tabel menjelaskan hasil penyerang yang telah di lakukan oleh pentester pada access poin 1 dan access poin 2. Dari dua penyerang yang dilakukan, dengan metode penyerangan yang sama menggunakan brute force atack, penyerangan pada acces poin 1 berhasil mendapatkan password untuk masuk ke wireless, Sedangkan penyerangan pada access poin 2 gagal mendapatkan password untuk masuk ke wireless.

Dapat di simpulkan bahwa access poin 1 memiliki password yang sangat mudah di tebak dan rentan tehadap serangan, sehingga perlu penanganan yang lebih baik serta pengunaan passphrase sebagai pengaman wireless. Penggunaan passphrase yang kuat merupakan jaminan keamanan untuk sebuah jaringan wireless.

\section{Data log Penyrangan}

Mempertimbangkan bahwa acces poin biasanya berjalan selama beberapa hari, penyerang yang gigih mungkin masih dapat berhasil menyerang acess poin yang mendukung WPS. Serangan ini berbiaya rendah dan memiliki jaminan keberhasilan yang tinggi dibandingkan dengan cracking WPA/WPA2-PSK.

\begin{tabular}{|l|l|l|l|l|l|}
\hline $\begin{array}{l}\text { Upaya } \\
\text { sebelum } \\
\text { mengunci }\end{array}$ & $\begin{array}{l}\text { Waktu } \\
\text { pengun } \\
\text { cian }\end{array}$ & $\begin{array}{l}\text { Upaya } \\
\text { per menit }\end{array}$ & $\begin{array}{l}\text { Waktu } \\
\text { serangan } \\
\text { maksimum }\end{array}$ & $\begin{array}{l}\text { Waktu } \\
\text { serangan } \\
\text { maksimum }\end{array}$ & komentar \\
\hline 11000 & 0detik & 46.15 & 3.97 menit & 0.17 hari & tidak terkunci \\
\hline$?$ & & 4.20 & 43,65 menit & 1,82jam & NetgearWGR614v10 \\
\hline 3 & 1detik & 2.82 & 65.08 menit & 2.71jam & Persyaratan untukWSC 2.0 \\
\hline 15 & 60detik & 0.25 & 737.31 menit & 30.72jam & Mengunci konfigurasi \\
\hline 10 & 60detik & 0.17 & 1103.97 & 46.00jam & $\begin{array}{l}\text { membuat brute force } \\
\text { kurang praktis }\end{array}$ \\
\hline 5 & 60detik & 0.08 & 2203.97 & 91.83jam \\
\hline
\end{tabular}

Karena hampir semua vendor router/acces poin utama memiliki perangkat bersertifikasi WPS dan WPS - PIN (Pencatat Eksternal) wajib untuk sertifikasi, diperkirakan banyak perangkat rentan terhadap serangan semacam ini.

Memiliki periode penguncian yang cukup lama kemungkinan besar bukan persyaratan untuk sertifikasi. Namun itu mungkin menjadi persyaratan dalam Spesifikasi WSC (baru) Versi 28. Saya menghubungi Wi-Fi Alliance tentang hal ini mereka belum merespons.

Kolaborasi dengan vendor akan diperlukan untuk mengidentifikasi semua perangkat yang rentan. Terserah vendor untuk menerapkan mitigasi dan merilis firmware baru.

Pengguna akhir yang terkena dampak harus diberi tahu tentang kerentanan ini dan disarankan untuk menonaktifkan WPS ataumemperbarui firmware mereka ke versi yang lebih aman (jika tersedia).

\section{KESIMPULAN DAN SARAN}

\section{1. kesimpulan}

Berdasarkan analisis dan penjelasan yang telah dikemukakan sebelumnya, dapat disimpulkan dari hasil analisis keamanan jaringan wireless dengan metode penetration testing di RS H.L Manambai Abdulkadir hasil dari uraian pentest di RS H.L Manambai Abdulkadir memiliki banyak celah yang harus lebih diperhatikan oleh unit IT RS H.LManambai Abdulkadir karena banyak sekali kesempatan bagi siapapun untuk menyerang kelemahan sistem keamanan jaringan terutama keamanan jaringan wireless.

\section{SARAN}

Dari hasil kesimpulan di atas, terdapat beberapa saran yang penullis berikan untuk pihakpihak yang terkait maupun untuk penelitian selanjutnya.

1. Untuk mendapatkan jaringan wireless yang lebih aman, gunakan RADIUS server dengan otentikasi Captive Portal yang bisa mengurangi resiko-resiko terjadinya ilegal acces di RS H.L Manambai Abdulkadir.

2. Menganalisis celah-celah keamanan akses lainnya pada access poin dengan mengikuti perkembangan teknologi yang semakin maju.

3. Mengembangkan teknik serangan pada access poin menggunakan beberapa metode penyerangan lainnya seperi dengan sistem operasi dan Tols yang lebih baru.

4. Di harapkan untuk penelitian selanjutnya dapat menerapkan implementasi dalam meningkatkan keamanan jaringan khususnya pada access poin.

\section{DAFTAR PUSTAKA}

[1] Bayu, Imam Kreshna, Muh Yamin, And LM Fid Aksara. "Analisa Keamanan Jaringan WLAN Dengan Metode Penetration Testing (Studi Kasus: Laboratorium Sistem Informasi Dan Programming Teknik Informatika UHO)." Semantik 3.2 (2017).

[2] Sari, Desi Maya, Muh Yamin, And LM Bahtiar Aksara."Analisis Sistem Keamanan Jaringan Wireless (Wep, Wpapsk/Wpa2psk) Mac Address, Menggunakan Metode Penetration Testing." Semantik 3.2 (2017).

[3] Sabdho, Harry Dwi, And Maria Ulfa. "Analisis Keamanan Jaringan Wireless Menggunakan Metode Penetration Testing Pada Kantor PT Mora Telematika Indonesia Regional Palembang." Prosiding Semhavok 1.1 (2018): 15-24. 
[4] Dwiyatno, Saleh. "Analisis Monitoring Sistem Jaringan Komputer Menggunakan Software Nmap."PROSISKO: Jurnal Pengembangan Riset Dan Observasi Sistem Komputer 7.2 (2020): 108-115

[5] Suharmanto, Abraham Y., Arie SM Lumenta, and Xaverius BN Najoan. "Analisa Keamanan Jaringan Wireless Di Universitas Sam Ratulangi." Jurnal Teknik Informatika 13.3 (2018).

[6] Ismail, Rizky Wahyu, and Rully Pramudita. "Metode Penetration Testing pada Keamanan Jaringan Wireless Wardriving PT. Puma Makmur Aneka Engineering Bekasi." Jurnal Mahasiswa Bina Insani 5.1 (2020): 53-62.

[7] Agung Suprapto, M.Eng. Pengantar Jaringan Komputer 2020.

[8] Creswell, J. W. (2013). Research Design Pendekatan Kualitatif, Kuantitatif, Dan Mixed.Yogyakarta: Pustaka Pelajar

[9] Kespersky.2021 Burte Force Attacks.Https://Www.Kespersky.Com. Diakeses Pada Tangan 27 September 2021

[10] Georgia Weidman. Penetration Testin,. 2014

[11] Nurul Hayati (2020) , M.Cs. Buku Ajar Sistem Keamanan;Tanjungpinang

[12] Sugiyono (2017), Metode Penelitian Data Kualitatif, Kuantitatif, Dan R\&D Alfabeta;Bandung 